\title{
Weight Science: Evaluating the Evidence for a Paradigm Shift
}

Linda Bacon ${ }^{1 *}$, Lucy Aphramor ${ }^{2,3}$

\begin{abstract}
Current guidelines recommend that "overweight" and "obese" individuals lose weight through engaging in lifestyle modification involving diet, exercise and other behavior change. This approach reliably induces short term weight loss, but the majority of individuals are unable to maintain weight loss over the long term and do not achieve the putative benefits of improved morbidity and mortality. Concern has arisen that this weight focus is not only ineffective at producing thinner, healthier bodies, but may also have unintended consequences, contributing to food and body preoccupation, repeated cycles of weight loss and regain, distraction from other personal health goals and wider health determinants, reduced self-esteem, eating disorders, other health decrement, and weight stigmatization and discrimination. This concern has drawn increased attention to the ethical implications of recommending treatment that may be ineffective or damaging. A growing trans-disciplinary movement called Health at Every Size (HAES) challenges the value of promoting weight loss and dieting behavior and argues for a shift in focus to weight-neutral outcomes. Randomized controlled clinical trials indicate that a HAES approach is associated with statistically and clinically relevant improvements in physiological measures (e.g., blood pressure, blood lipids), health behaviors (e.g., eating and activity habits, dietary quality), and psychosocial outcomes (such as self-esteem and body image), and that HAES achieves these health outcomes more successfully than weight loss treatment and without the contraindications associated with a weight focus. This paper evaluates the evidence and rationale that justifies shifting the health care paradigm from a conventional weight focus to HAES.
\end{abstract}

\section{Introduction}

Concern regarding "overweight" and "obesity" is reflected in a diverse range of policy measures aimed at helping individuals reduce their body mass index $(\mathrm{BMI})^{1}$. Despite attention from the public health establishment, a private weight loss industry estimated at $\$ 58.6$ billion annually in the United States [1], unprecedented levels of body dissatisfaction [2] and repeated attempts to lose weight $[3,4]$, the majority of individuals are unable to maintain weight loss over the long term and do not achieve the putative benefits of improved morbidity and mortality [5]. Concern has arisen that this weight focused paradigm is not only ineffective at producing thinner, healthier bodies, but also damaging, contributing to food and body preoccupation, repeated cycles of weight loss and regain, distraction from other personal health goals and wider

\footnotetext{
* Correspondence: linda@lindabacon.org

'University of California, Davis, and City College of San Francisco, Box S-80,

City College of San Francisco, 50 Phelan Avenue, San Francisco,

CA 94112, USA

Full list of author information is available at the end of the article
}

health determinants, reduced self-esteem, eating disorders, other health decrement, and weight stigmatization and discrimination [6-8]. As evidence-based competencies are more firmly embedded in health practitioner standards, attention has been given to the ethical implications of recommending treatment that may be ineffective or damaging $[5,9]$.

A growing trans-disciplinary movement called Health at Every Size ${ }^{\text {SM }}$ (HAES) $^{2}$ shifts the focus from weight management to health promotion. The primary intent of HAES is to support improved health behaviors for people of all sizes without using weight as a mediator; weight loss may or may not be a side effect.

HAES is emerging as standard practice in the eating disorders field: The Academy for Eating Disorders, Binge Eating Disorder Association, Eating Disorder Coalition, International Association for Eating Disorder Professionals, and National Eating Disorder Association explicitly support this approach [10]. Civil rights groups including the National Association to Advance Fat Acceptance and the Council on Size and Weight

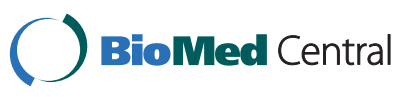


Discrimination also encourage HAES. An international professional organization, the Association for Size Diversity and Health, has developed, composed of individual members across a wide span of professions who are committed to HAES principles.

\section{Health at Every Size: A Review of Randomized Controlled Trials}

Several clinical trials comparing HAES to conventional obesity treatment have been conducted. Some investigations were conducted before the name "Health at Every Size" came into common usage; these earlier studies typically used the terms "non-diet" or "intuitive eating" and included an explicit focus on size acceptance (as opposed to weight loss or weight maintenance). A Pub Med search for "Health at Every Size" or "intuitive eating" or "non-diet" or "nondiet" revealed 57 publications. Randomized controlled trials (RCTs) were vetted from these publications, and additional RCTs were vetted from their references. Only studies with an explicit focus on size acceptance were included.

Evidence from these six RCTs indicates that a HAES approach is associated with statistically and clinically relevant improvements in physiological measures (e.g. blood pressure, blood lipids), health behaviors (e.g. physical activity, eating disorder pathology) and psychosocial outcomes (e.g, mood, self-esteem, body image) [11-20]. (See Table 1.) All studies indicate significant improvements in psychological and behavioral outcomes; improvements in self-esteem and eating behaviors were particularly noteworthy $[11-14,16,17,19,20]$. Four studies additionally measured metabolic risk factors and three of these studies indicated significant improvement in at least some of these parameters, including blood pressure and blood lipids $[11,12,16,17,19,20]$. No studies found adverse changes in any variables.

A seventh RCT reported at a conference also found significantly positive results [18], as did a non-randomized controlled study [21] and five studies conducted without a control [22-26].

All of the controlled studies showed retention rates substantially higher than, or, in one instance, as high, as the control group, and all of the uncontrolled studies also showed high retention rates. Given the well-documented recidivism typical of weight loss programs $[5,27,28]$ and the potential harm that may arise $[29,30]$, this aspect is particularly noteworthy.

\section{Assumptions underlying the conventional (weight-focused) paradigm}

Dieting and other weight loss behaviors are popular in the general population and widely encouraged in public health policy and health care practice as a solution for the "problem" of obesity. There is increasing concern about the endemic misrepresentation of evidence in these weight management policies [5,8]. Researchers have demonstrated ways in which bias and convention interfere with robust scientific reasoning such that obesity research seems to "enjoy special immunity from accepted standards in clinical practice and publishing ethics" [5,8,31]. This section discusses the assumptions that underlie the current weight-focused paradigm, presenting evidence that contests their scientific merit and challenges the value of promoting weight management as a public health measure.

\section{Assumption: Adiposity poses significant mortality risk}

Evidence: Except at statistical extremes, body mass index (BMI) - or amount of body fat - only weakly predicts longevity [32]. Most epidemiological studies find that people who are overweight or moderately obese live at least as long as normal weight people, and often longer [32-35]. Analysis of the National Health and Nutrition Examination Surveys I, II, and III, which followed the largest nationally representative cohort of United States adults, determined that greatest longevity was in the overweight category [32]. As per the report, published in the Journal of the American Medical Association and reviewed and approved by the Centers for Disease Control and Prevention and the National Cancer Institute, "[this] finding is consistent with other results reported in the literature." Indeed, the most comprehensive review of the research pooled data for over 350,000 subjects from 26 studies and found overweight to be associated with greater longevity than normal weight [36]. More recently, Janssen analyzed data in the elderly (among whom more than 70 percent of all deaths occur) - also from 26 published studies - and similarly found no evidence of excess mortality associated with overweight [37]. The Americans' Changing Lives study came to a similar conclusion, indicating that "when socioeconomic and other risk factors are controlled for, obesity is not a significant risk factor for mortality; and... for those 55 or older, both overweight and obesity confer a significant decreased risk of mortality." [38] The most recent analysis, published in the New England Journal of Medicine, concluded that overweight was associated with increased risk, but only arrived at this conclusion after restricting the analysis by excluding 78 percent of the deaths [39]. They also used a reference category much narrower than the entire "normal weight" category used by most other studies, which also contributed to making the relative risk for overweight higher.

There is a robust pattern in the epidemiological literature that has been named the "obesity paradox" [40,41]: obesity is associated with longer survival in many diseases. For example, obese persons with type 2 diabetes [42], hypertension [43,44], cardiovascular disease [41,45], 
Table 1 Randomized controlled HAES studies reported in peer-reviewed journals

\begin{tabular}{|c|c|c|c|c|c|c|c|c|c|}
\hline \multirow[t]{2}{*}{ Investigation } & \multirow[t]{2}{*}{ Group type $^{a}(n)$} & \multirow[t]{2}{*}{ Population } & \multirow{2}{*}{$\begin{array}{c}\text { Number } \\
\text { of } \\
\text { treatment } \\
\text { sessions }\end{array}$} & \multirow{2}{*}{$\begin{array}{c}\text { Follow-up } \\
\text { (number } \\
\text { of weeks } \\
\text { post } \\
\text { treatment) }\end{array}$} & \multirow[t]{2}{*}{ Attrition } & \multicolumn{3}{|c|}{ Improvements } & \multirow{2}{*}{$\begin{array}{l}\text { Decre- } \\
\text { ments }\end{array}$} \\
\hline & & & & & & Physio-logic & $\begin{array}{c}\text { Health } \\
\text { behaviors }\end{array}$ & Psycho-social & \\
\hline $\begin{array}{l}\text { Provencher, } \\
\text { et al., 2009 } \\
{[17] \text { and }} \\
2007[20]\end{array}$ & $\begin{array}{l}\text { HAES }(n=48) \text {; } \\
\text { social support }(n= \\
48) ; \text { control }(n=48)\end{array}$ & $\begin{array}{l}\text { Overweight } \\
\text { and obese } \\
\text { women }\end{array}$ & 15 & 26 & $\begin{array}{l}8 \% \\
19 \% \\
21 \%\end{array}$ & Not evaluated & $\begin{array}{l}\text { Eating } \\
\text { behaviors }\end{array}$ & Not evaluated & None \\
\hline $\begin{array}{l}\text { Bacon et al, } \\
2005[11] \\
\text { and 2002[19] }\end{array}$ & $\begin{array}{l}\text { HAES }(n=39) ; \text { diet } \\
(n=39)\end{array}$ & $\begin{array}{l}\text { Obese } \\
\text { women, } \\
\text { chronic } \\
\text { dieters }\end{array}$ & 30 & 52 & $\begin{array}{l}8 \% \\
42 \%\end{array}$ & $\begin{array}{l}\text { LDL, systolic blood } \\
\text { pressure }\end{array}$ & $\begin{array}{l}\text { Activity, } \\
\text { binge } \\
\text { eating }\end{array}$ & $\begin{array}{l}\text { Self esteem, } \\
\text { depression, body } \\
\text { dissatisfact-ion, } \\
\text { body image, } \\
\text { interoceptive } \\
\text { awareness }\end{array}$ & None \\
\hline $\begin{array}{l}\text { Rapaport et } \\
\text { al., 2000[16] }\end{array}$ & $\begin{array}{l}\text { Modified } \\
\text { cognitive- } \\
\text { behavioral } \\
\text { treatment ( } n=37) \\
\text { cognitive behavioral } \\
\text { treatment }(n=38)\end{array}$ & $\begin{array}{l}\text { Overweight } \\
\text { and obese } \\
\text { women }\end{array}$ & 10 & 52 & $\begin{array}{l}16 \% ; \\
16 \%\end{array}$ & $\begin{array}{l}\text { Total cholesterol }^{\mathbf{b}} \text {, } \\
\text { LDL cholesterol }^{\mathbf{b}} \text {, } \\
\text { systolic blood }^{\mathbf{b}} \text {, diastolic } \\
\text { pressure }^{\mathbf{b}} \text {, diood pressure } \\
\text { blood }^{\mathbf{b}}\end{array}$ & $\begin{array}{l}\text { Activity }^{\mathbf{b}} \text {, } \\
\text { dietary }^{\mathbf{b}} \\
\text { quality }^{\mathbf{b}}\end{array}$ & $\begin{array}{l}\text { Emotional well- } \\
\text { being }^{\mathbf{b}} \text {, distress } \\
\mathbf{b}\end{array}$ & None \\
\hline $\begin{array}{l}\text { Ciliska, } 1998 \\
{[12]}\end{array}$ & $\begin{array}{l}\text { Psycho- } \\
\text { educational ( } n= \\
\text { 29); education only } \\
(n=26) \text {, waitlist } \\
\text { control }(n=23)\end{array}$ & $\begin{array}{l}\text { Obese } \\
\text { women }\end{array}$ & 12 & 52 & $\begin{array}{l}14 \% ; \\
23 \% ; \\
41 \%\end{array}$ & $\begin{array}{l}\text { Diastolic blood } \\
\text { pressure }\end{array}$ & $\begin{array}{l}\text { Binge } \\
\text { eating }\end{array}$ & $\begin{array}{l}\text { Self-esteem, body } \\
\text { dissatisfact-ion, } \\
\text { depression }\end{array}$ & None \\
\hline $\begin{array}{l}\text { Goodrick et } \\
\text { al., 1998[13] }\end{array}$ & $\begin{array}{l}\text { Nondiet }(n=62) \\
\text { diet }(n=65) ; \text { wait- } \\
\text { list control }(n=58)\end{array}$ & $\begin{array}{l}\text { Overweight } \\
\text { and obese } \\
\text { women, } \\
\text { binge-eaters }\end{array}$ & 50 & 78 & $\begin{array}{c}\text { Not } \\
\text { reported }\end{array}$ & Not evaluated & $\begin{array}{c}\text { Binge- } \\
\text { eating, } \\
\text { exercise }^{\mathbf{b}}\end{array}$ & Not evaluated & None \\
\hline $\begin{array}{l}\text { Tanco, et al., } \\
1998 \text { [14] }\end{array}$ & $\begin{array}{l}\text { Cognitive group } \\
\text { treatment }(n=20) ; \\
\text { weight loss }(n= \\
21) ; \text { waitlist control } \\
(n=19)\end{array}$ & $\begin{array}{l}\text { Obese } \\
\text { women }\end{array}$ & 8 & 26 & $\begin{array}{l}10 \% ; \\
10 \% ; \\
32 \%\end{array}$ & Not evaluated & $\begin{array}{c}\text { Not } \\
\text { evaluated }\end{array}$ & $\begin{array}{l}\text { Depression, } \\
\text { anxiety, eating- } \\
\text { related psycho- } \\
\text { pathology, } \\
\text { perception of self- } \\
\text { control }\end{array}$ & None \\
\hline
\end{tabular}

${ }^{a}$ HAES group listed first and in bold. (The names reflect those used in the publication.)

${ }^{\mathrm{b}}$ Improvement in HAES group, but not statistically different from the control.

and chronic kidney disease [46] all have greater longevity than thinner people with these conditions [47-49]. Also, obese people who have had heart attacks, coronary bypass [50], angioplasty [51] or hemodialysis [52] live longer than thinner people with these histories [49]. In addition, obese senior citizens live longer than thinner senior citizens [53].

The idea that "this is the first generation of children that may have a shorter life expectancy than their parents" is commonly expressed in scientific journals [54] and popular press articles [55], even appearing in Congressional testimony by former Surgeon General Richard Carmona [56] and a 2010 report from the White House Task Force on Childhood Obesity [57]. When citation is provided, it refers to an opinion paper published in the New England Journal of Medicine [54], which offered no statistical evidence to support the claim. Life expectancy increased dramatically during the same time period in which weight rose (from 70.8 years in 1970 to 77.8 years in 2005) [58]. Both the World Health Organization and the Social Security Administration project life expectancy will continue to rise in coming decades $[59,60]$.

\section{Assumption: Adiposity poses significant morbidity risk}

Evidence: While it is well established that obesity is associated with increased risk for many diseases, causation is less well-established. Epidemiological studies rarely acknowledge factors like fitness, activity, nutrient intake, weight cycling or socioeconomic status when considering connections between weight and disease. Yet all play a role in determining health risk. When studies do control for these factors, increased risk of disease disappears or is significantly reduced [61]. (This is less true at statistical extremes.) It is likely that these other factors increase disease risk at the same time they increase the risk of weight gain. 
Consider weight cycling as an example. Attempts to lose weight typically result in weight cycling, and such attempts are more common among obese individuals [62]. Weight cycling results in increased inflammation, which in turn is known to increase risk for many obesity-associated diseases [63]. Other potential mechanisms by which weight cycling contributes to morbidity include hypertension, insulin resistance and dyslipidemia [64]. Research also indicates that weight fluctuation is associated with poorer cardiovascular outcomes and increased mortality risk [64-68]. Weight cycling can account for all of the excess mortality associated with obesity in both the Framingham Heart Study [69] and the National Health and Nutrition Examination Survey (NHANES) [70]. It may be, therefore, that the association between weight and health risk can be better attributed to weight cycling than adiposity itself [63].

As another example, consider type 2 diabetes, the disease most highly associated with weight and fat distribution. There is increasing evidence that poverty and marginalization are more strongly associated with type 2 diabetes than conventionally-accepted risk factors such as weight, diet or activity habits [30,71-73]. A large Canadian report produced in 2010, for example, found that low income was strongly associated with diabetes even when BMI (and physical activity) was accounted for [73]. Also, much evidence suggests that insulin resistance is a product of an underlying metabolic disturbance that predisposes the individual to increased fat storage due to compensatory insulin secretion [61,74-78]. In other words, obesity may be an early symptom of diabetes as opposed to its primary underlying cause.

Hypertension provides another example of a condition highly associated with weight; research suggests that it is two to three times more common among obese people than lean people [79]. To what extent hypertension is caused by adiposity, however, is unclear. That BMI correlates more strongly with blood pressure than percent body fat [80] indicates that the association between BMI and blood pressure results from higher lean mass as opposed to fat mass. Also, the association may have more to do with the weight cycling that results from trying to control weight than the actual weight itself $[48,81,82]$. One study conducted with obese individuals determined that weight cycling was strongly positively associated with incident hypertension [82]. Another study showed that obese women who had dieted had high blood pressure, while those who had never been on a diet had normal blood pressure [67]. Rat studies also show that obese rats that have weight cycled have very high blood pressures compared to obese rats that have not weight cycled $[83,84]$. This finding could also explain the weak association between obesity and hypertension in cultures where dieting is uncommon $[48,85]$. Additionally, it is well documented that obese people with hypertension live significantly longer than thinner people with hypertension [43,86-88] and have a lower risk of heart attack, stroke, or early death [45]. Rather than identifying health risk, as it does in thinner people, hypertension in heavier people may simply be a requirement for pumping blood through their larger bodies [89].

It is also notable that the prevalence of hypertension dropped by half between 1960 and 2000, a time when average weight sharply increased, declining much more steeply among those deemed overweight and obese than among thinner individuals [90]. Incidence of cardiovascular disease also plummeted during this time period and many common diseases now emerge at older ages and are less severe [90]. (The notable exception is diabetes, which showed a small, non-significant increase during this time period [90].) While the decreased morbidity can at least in part be attributed to improvements in medical care, the point remains that we are simply not seeing the catastrophic disease consequences predicted to result from the "obesity epidemic."

\section{Assumption: Weight loss will prolong life}

Evidence: Most prospective observational studies suggest that weight loss increases the risk of premature death among obese individuals, even when the weight loss is intentional and the studies are well controlled with regard to known confounding factors, including hazardous behavior and underlying diseases [91-96]. Recent review of NHANES, for example, a nationally representative sample of ethnically diverse people over the age of fifty, shows that mortality increased among those who lost weight [97].

While many short-term weight loss intervention studies do indicate improvements in health measures, because the weight loss is always accompanied by a change in behavior, it is not known whether or to what extent the improvements can be attributed to the weight loss itself. Liposuction studies that control for behavior change provide additional information about the effects of weight (fat) loss itself. One study which explicitly monitored that there were no changes in diet and activity for 10-12 weeks post abdominal liposuction is a case in point. Participants lost an average of $10.5 \mathrm{kgs}$ but saw no improvements in obesity-associated metabolic abnormalities, including blood pressure, triglycerides, cholesterol, or insulin sensitivity [98]. (Note that liposuction removes subcutaneous fat, not the visceral fat that is more highly associated with disease, and these results should be interpreted carefully.)

In most studies on type 2 diabetes, the improvement in glycemic control is seen within days, before significant 
weight or fat is lost. Evidence also challenges the assumption that weight loss is associated with improvement in long-term glycemic control, as reflected in HbA1c values $[99,100]$. One review of controlled weight-loss studies for people with type 2 diabetes showed that initial improvements were followed by a deterioration back to starting values six to eighteen months after treatment, even when the weight loss was maintained [101].

Furthermore, health benefits associated with weight loss rarely show a dose response (in other words, people who lose small amounts of weight generally get as much health benefit from the intervention as those who lose larger amounts).

These data suggest that the behavior change as opposed to the weight loss itself may play a greater role in health improvement.

\section{Assumption: Anyone who is determined can lose weight and keep it off through appropriate diet and exercise}

Evidence: Long-term follow-up studies document that the majority of individuals regain virtually all of the weight that was lost during treatment, regardless of whether they maintain their diet or exercise program $[5,27]$. Consider the Women's Health Initiative, the largest and longest randomized, controlled dietary intervention clinical trial, designed to test the current recommendations. More than 20,000 women maintained a low-fat diet, reportedly reducing their calorie intake by an average of 360 calories per day [102] and significantly increasing their activity [103]. After almost eight years on this diet, there was almost no change in weight from starting point (a loss of $0.1 \mathrm{~kg}$ ), and average waist circumference, which is a measure of abdominal fat, had increased $(0.3 \mathrm{~cm})$ [102].

A panel of experts convened by the National Institutes of Health determined that "one third to two thirds of the weight is regained within one year [after weight loss], and almost all is regained within five years." [28] More recent review finds one-third to two-thirds of dieters regain more weight than was lost on their diets; "In sum," the authors report, "there is little support for the notion that diets lead to lasting weight loss or health benefits [5]." Other reviews demonstrate the unreliability of conventional claims of sustained weight loss $[104,105]$. There is a paucity of long term data regarding surgical studies, but emerging data indicates gradual post-surgery weight regain as well $[106,107]$. Weight loss peaks about one year postoperative, after which gradual weight regain is the norm.

\section{Assumption: The pursuit of weight loss is a practical and positive goal}

Evidence: As discussed earlier, weight cycling is the most common result of engaging in conventional dieting practices and is known to increase morbidity and mortality risk. Research identifies many other contraindications to the pursuit of weight loss. For example, dieting is known to reduce bone mass, increasing risk for osteoporosis [108-111]; this is true even in an obese population, though obesity is typically associated with reduced risk for osteoporosis [108]. Research also suggests that dieting is associated with increased chronic psychological stress and cortisol production, two factors known to increase disease risk [112]. Also, there is emerging evidence that persistent organic pollutants (POPs), which bioaccumulate in adipose tissue and are released during its breakdown, can increase risk of various chronic diseases including type 2 diabetes [113,114], cardiovascular disease [115] and rheumatoid arthritis [116]; two studies document that people who have lost weight have higher concentration of POPs in their blood $[117,118]$. One review of the diabetes literature indicates "that obese persons that (sic) do not have elevated POPs are not at elevated risk of diabetes, suggesting that the POPs rather than the obesity per se is responsible for the association" [114].

Positing the value of weight loss also supports widespread anxiety about weight $[119,120]$. Evidence from the eating disorder literature indicates an emphasis on weight control can promote eating disordered behaviors [7]. Prospective studies show that body dissatisfaction is associated with binge eating and other eating disordered behaviors, lower levels of physical activity and increased weight gain over time $[121,122]$. Many studies also show that dieting is a strong predictor of future weight gain [66,123-128].

Another unintended consequence of the weight loss imperative is an increase in stigmatization and discrimination against fat individuals. Discrimination based on weight now equals or exceeds that based on race or gender [129]. Extensive research indicates that stigmatizing fat demotivates, rather than encourages, health behavior change [130]. Adults who face weight stigmatization and discrimination report consuming increased quantities of food [131-134], avoiding exercise [133,135-137], and postponing or avoiding medical care (for fear of experiencing stigmatization) [138]. Stigmatization and bias on the part of health care practitioners is welldocumented, resulting in lower quality care $[139,140]$.

\section{Assumption: The only way for overweight and obese people to improve health is to lose weight}

Evidence: That weight loss will improve health over the long-term for obese people is, in fact, an untested hypothesis. One reason the hypothesis is untested is because no methods have proven to reduce weight longterm for a significant number of people. Also, while normal weight people have lower disease incidence than 
obese individuals, it is unknown if weight loss in individuals already obese reduces disease risk to the same level as that observed in those who were never obese [91,93].

As indicated by research conducted by one of the authors and many other investigators, most health indicators can be improved through changing health behaviors, regardless of whether weight is lost [11]. For example, lifestyle changes can reduce blood pressure, largely or completely independent of changes in body weight [11,141-143]. The same can be said for blood lipids [11,143-145]. Improvements in insulin sensitivity and blood lipids as a result of aerobic exercise training have been documented even in individuals who gained body fat during the intervention [145,146].

\section{Assumption: Obesity-related costs place a large burden on the economy, and this can be corrected by focused attention to obesity treatment and prevention}

Evidence: The health cost attributed to obesity in the United States is currently estimated to be $\$ 147$ billion annually [147] and this cost estimate has been used to justify efforts at obesity treatment and prevention. Although this estimate has been granted credence by health experts, the word "estimate" is important to note: as the authors state, most of the cost changes are not "statistically different from zero." Also, the estimate fails to account for many potentially confounding variables, among them physical activity, nutrient intake, history of weight cycling, degree of discrimination, access to (quality) medical care, etc. All are independently correlated with both weight and health and could play a role in explaining the costs associated with having a BMI over 30. Nor does it account for costs associated with unintended consequences of positing the value of a weight focus, which may include eating disorders, diet attempts, weight cycling, reduced self-esteem, depression, and discrimination.

Because BMI is considered a risk factor for many diseases, obese persons are automatically relegated to greater testing and treatment, which means that positing $\mathrm{BMI}$ as a risk factor results in increased costs, regardless of whether BMI itself is problematic. Yet using BMI as a proxy for health may be more costly than addressing health directly. Consider, for example, the findings of a study which examined the "healthy obese" and the "unhealthy normal weight" populations [148]. The study identified six different risk factors for cardiometabolic health and included subjects in the "unhealthy" group if they had two or more risk factors, making it a more stringent threshold of health than that used in categorizing metabolic syndrome or diabetes. The study found a substantial proportion of the overweight and obese population, at every age, who were healthy and a substantial proportion of the "normal weight" group who were unhealthy. Psychologist Deb Burgard examined the costs of overlooking the normal weight people who need treatment and over-treating the obese people who do not (personal communication, March 2010). She found that BMI profiling overlooks 16.3 million "normal weight" individuals who are not healthy and identifies 55.4 million overweight and obese people who are not ill as being in need of treatment (see Table 2). When the total population is considered, this means that 31 percent of the population is mis-identified when BMI is used as a proxy for health.

The weight bias inherent in BMI profiling may actually result in higher costs and sicker people. As an example, consider a 2009 study published in the American Journal of Public Health (96). The authors compared people of similar age, gender, education level, and rates of diabetes and hypertension, and examined how often they reported feeling sick over a 30-day period. Results indicated that body image had a much bigger impact on health than body size. In other words, two equally fat women would have very different health outcomes, depending on how they felt about their bodies. Likewise, two women with similar body insecurities would have similar health outcomes, even if one were fat and the other thin. These results suggest that the stigma associated with being fat is a major contributor to obesity-associated disease. BMI and health are only weakly related in cultures where obesity is not stigmatized, such as in the South Pacific $[48,149]$.

\section{Health at every size: shifting the paradigm from weight to health}

This section explains the rationale supporting some of the significant ways in which the HAES paradigm differs from the conventional weight-focused paradigm. The following topics are addressed:

1) HAES encourages body acceptance as opposed to weight loss or weight maintenance;

2) HAES supports reliance on internal regulatory processes, such as hunger and satiety, as opposed to encouraging cognitively-imposed dietary restriction; and

3) HAES supports active embodiment as opposed to encouraging structured exercise.

\section{Encouraging Body Acceptance}

Conventional thought suggests that body discontent helps motivate beneficial lifestyle change $[150,151]$. However, as discussed previously in the section on the pursuit of weight loss, evidence suggests the opposite: promoting body discontent instead induces harm $[122,133,134,152]$, resulting in less favorable lifestyle choices. A common aphorism expressed in the HAES community is that "if shame were effective motivation, 
Table 2 Cost of Using BMI as a Proxy for Health ${ }^{\mathrm{a}}$

\begin{tabular}{|c|c|c|c|c|}
\hline & & $\begin{array}{c}\text { Abnormal } \\
\text { cardiometabolic profile }\end{array}$ & $\begin{array}{c}\text { Normal } \\
\text { cardiometabolic profile }\end{array}$ & TOTAL \\
\hline Untreated & $\begin{array}{l}\text { "Normal" weight } \\
(\mathrm{BMI}=18.5-24.9)\end{array}$ & $\begin{array}{c}23.5 \% \\
(16.3 \text { million people })^{b}\end{array}$ & $\begin{array}{c}\text { 76.5\% } \\
\text { (53.0 million people) }\end{array}$ & $\begin{array}{c}100 \% \\
\text { (69.3 million people) } \\
\end{array}$ \\
\hline \multirow[t]{2}{*}{ Treated } & $\begin{array}{l}\text { "Overweight" } \\
(\mathrm{BMI}=25.0-29.9)\end{array}$ & $\begin{array}{c}48.7 \% \\
\text { (34.1 million people) }\end{array}$ & $\begin{array}{c}51.3 \% \\
(35.9 \text { million people })^{c}\end{array}$ & $\begin{array}{c}100 \% \\
\text { (70.0 million people) }\end{array}$ \\
\hline & $\begin{array}{l}\text { "Obese" } \\
(\mathrm{BMI} \geq 30.0)\end{array}$ & $\begin{array}{c}68.3 \% \\
\text { (42.0 million people) }\end{array}$ & $\begin{array}{c}31.7 \% \\
(19.5 \text { million people })^{c}\end{array}$ & $\begin{array}{c}100 \% \\
\text { (61.5 million people) }\end{array}$ \\
\hline TOTAL & & $\begin{array}{c}46 \% \\
92.4 \text { million people }\end{array}$ & $\begin{array}{c}54 \% \\
108.4 \text { million people }\end{array}$ & $\begin{array}{c}100 \% \\
200.8 \text { million people }\end{array}$ \\
\hline
\end{tabular}

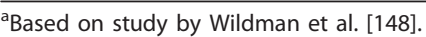

${ }^{\mathrm{b}}$ False negative: 16.3 million of 92.4 million (17.6\%) who have abnormal cardiometabolic profile are overlooked.

${ }^{\mathrm{C}}$ False positive: 55.4 million of 131.5 million (42\%) are identified as ill who are not.

there wouldn't be many fat people." Mounting evidence suggests this belief is unfounded and detrimental $[8,152]$. Promoting one body size as more favorable than another also has ethical consequences [120], contributing to shaming and discrimination.

Compassion-focused behavior change theory emerging from the eating disorders field suggests that self-acceptance is a cornerstone of self-care, meaning that people with strong self-esteem are more likely to adopt positive health behaviors $[153,154]$. The theory is borne out in practice: HAES research shows that by learning to value their bodies as they are right now, even when this differs from a desired weight or shape or generates ambivalent feelings, people strengthen their ability to take care of themselves and sustain improvements in health behaviors $[8,11]$.

Critics of HAES express concern that encouraging body acceptance will lead individuals to eat with abandon and disregard dietary considerations, resulting in weight gain. This has been disproven by the evidence; no randomized controlled HAES study has resulted in weight gain, and all studies that report on dietary quality or eating behavior indicate improvement or at least maintenance [11,14-23]. This is in direct contrast to dieting behavior, which is associated with weight gain over time [66,123-128].

\section{Supporting Intuitive Eating}

Conventional recommendations view conscious efforts to monitor and restrict food choices as a necessary aspect of eating for health or weight control [155]. The underlying belief is that cognitive monitoring is essential for keeping appetite under control and that without these injunctions people would make nutritionally inadvisable choices, including eating to excess. The evidence, however, disputes the value of encouraging external regulation and restraint as a means for weight control: several large scale studies demonstrate that eating restraint is actually associated with weight gain over time [66,123-126].
In contrast, HAES teaches people to rely on internal regulation, a process dubbed intuitive eating [156], which encourages them to increase awareness of their body's response to food and learn how to make food choices that reflect this "body knowledge." Food is valued for nutritional, psychological, sensual, cultural and other reasons. HAES teaches people to make connections between what they eat and how they feel in the short- and medium-term, paying attention to food and mood, concentration, energy levels, fullness, ease of bowel movements, comfort eating, appetite, satiety, hunger and pleasure as guiding principles.

The journey towards adopting intuitive eating is typically a process one engages in over time. Particularly for people with a long history of dieting, other self-imposed dietary restriction, or body image concerns, it can feel very precarious to let go of old habits and attitudes and risk trying new ways of relating to food and self. Coming to eat intuitively happens gradually as old beliefs about food, nutrition and eating are challenged, unlearned and replaced with new ones.

A large popular literature has accumulated that supports individuals in developing intuitive eating skills [8,156-160]. (Intuitive eating is also known in the literature as "attuned eating" or "mindful eating." Note that intuitive eating is sometimes promoted as a means to weight loss and in that context is inconsistent with a HAES approach.)

There is considerable evidence that intuitive eating skills can be learned $[11,18,161]$, and that intuitive eating is associated with improved nutrient intake [162], reduced eating disorder symptomatology [17,18,163-165] - and not with weight gain [11,13,16-18]. Several studies have found intuitive eating to be associated with lower body mass $[162,163,166,167]$.

\section{Supporting Active Embodiment}

HAES encourages people to build activity into their dayto-day routines and focuses on helping people find 
enjoyable ways of being active. The goal is to promote well-being and self-care rather than advising individuals to meet set guidelines for frequency and intensity of exercise. Active living is promoted for a range of physical, psychological and other synergistic benefits which are independent of weight loss. Myths around weight control and exercise are explicitly challenged. Physical activity is also used in HAES as a way of healing a sense of body distrust and alienation from physicality that may be experienced when people are taught to over-ride embodied internal signals in pursuit of externally derived goals, such as commonly occurs in dieting. In addition, some HAES programs have used physical activity sessions, along with other activities such as art and relaxation, to further a community development agenda, creating volunteer, training and employment opportunities and addressing issues of isolation, poor self-esteem and depression among course participants.

\section{Clinical Ethics}

There are serious ethical concerns regarding the continued use of a weight-centered paradigm in current practice in relation to beneficence and nonmaleficence. Beneficence concerns the requirement to effect treatment benefit. There is a paucity of literature to substantiate that the pursuit of weight control is beneficial, and a similar lack of evidence to support that weight loss is maintained over the long term or that programs aimed at prevention of weight gain are successful. Nonmaleficence refers to the requirement to do no harm. Much research suggests damage results from a weightcentered focus, such as weight cycling and stigmatization. Consideration of several dimensions of ethical practice - veracity, fidelity, justice and a compassionate response - suggests that the HAES paradigm shift may be required for professional ethical accountability [168].

\section{Public Health Ethics}

The new public health ethics advocates scrutiny of the values and structure of medical care, recognizing that the remedy to poor health and health inequalities does not lie solely in individual choices.

This ethicality has been adopted by HAES in several ways. HAES academics have highlighted the inherent limitations of an individualistic approach to conceptualizing health. Individual self-care is taken as a starting point for HAES programs, but, unlike more conventional interventions, the HAES ethos recognizes the structural basis of health inequities and understands empowerment as a process that effects collective change in advancing social justice [169]. HAES advocates have also stressed the need for action to challenge the thinness privilege and to better enable fat people's voices to be heard in and beyond health care $[8,170]$.
The hallmark theme of the new public health agenda is that it emphasizes the complexity of health determinants and the need to address systemic health inequities in order to improve population-wide health outcomes and reduce health disparities, making use of the evidence on the strong relationship between a person's social positioning and their health. For example, research since the 1950s has documented huge differences in cardiac health between and across socioeconomic gradients which has come to be recognized as arising from disparities in social standing and is articulated as the status syndrome [171]. Since weight tracks closely with socioeconomic class, obesity is a particularly potent marker of social disparity [172].

There is extensive research documenting the role of chronic stress in conditions conventionally described as obesity-associated, such as hypertension, diabetes and coronary heart disease [173]. These conditions are mediated through increased metabolic risk seen as raised cholesterol, raised blood pressure, raised triglycerides and insulin resistance. The increase in metabolic risk can in part be explained by a change in eating, exercise and drinking patterns attendant on coping with stress. However, changes in health behaviors do not fully account for the metabolic disturbances. Instead, stress itself alters metabolism independent of a person's lifestyle habits [174]. Thus, it has been suggested that psychological distress is the antecedent of high metabolic risk [175], which indicates the need to ensure health promotion policies utilize strategies known to reduce, rather than increase, psychological stress. In addition to the impact of chronic stress on health, an increasing body of international research, discussed earlier, recognizes particular pathways through which weight stigmatization and discrimination impact on health, health-seeking behaviors, and quality of health care [125-133].

Policies which promote weight loss as feasible and beneficial not only perpetuate misinformation and damaging stereotypes [176], but also contribute to a healthist, moralizing discourse which mitigates against socially-integrated approaches to health $[155,168$, $177,178]$. While access to size acceptance practitioners can ameliorate the harmful effects of discrimination in health care for individuals, systemic change is required to address the iatrogenic consequences of institutional size discrimination in and beyond health care, discrimination that impacts on people's opportunities and health.

Quite aside from the ethical arguments underscoring inclusive, non-discriminatory health care and civil rights, there are plausible metabolic pathways through which reducing weight stigma, by reducing inequitable social processes, can help alleviate the burden of poor health. 


\section{Conclusion}

From the perspective of efficacy as well as ethics, body weight is a poor target for public health intervention. There is sufficient evidence to recommend a paradigm shift from conventional weight management to Health at Every Size. More research that considers the unintended consequences of a weight focus can help to clarify the associated costs and will better allow practitioners to challenge the current paradigm. Continued research that includes larger sample sizes and more diverse populations and examines how best to deliver a Health at Every Size intervention, customized to specific populations, is called for.

We propose the following guidelines, which are supported by the Association for Size Diversity and Health (ASDAH), to assist professionals in implementing HAES. Our proposed guidelines are modified, with permission, from guidelines developed by the Academy for Eating Disorders for working with children [7].

- Interventions should meet ethical standards. They should focus on health, not weight, and should be referred to as "health promotion" and not marketed as "obesity prevention." Interventions should be careful to avoid weight-biased stigma, such as using language like "overweight" and "obesity."

- Interventions should seek to change major determinants of health that reside in inequitable social, economic and environmental factors, including all forms of stigma and oppression.

- Interventions should be constructed from a holistic perspective, where consideration is given to physical, emotional, social, occupational, intellectual, spiritual, and ecological aspects of health.

- Interventions should promote self-esteem, body satisfaction, and respect for body size diversity.

- Interventions should accurately convey the limited impact that lifestyle behaviors have on overall health outcomes.

- Lifestyle-oriented elements of interventions that focus on physical activity and eating should be delivered from a compassion-centered approach that encourages self-care rather than as prescriptive injunctions to meet expert guidelines.

- Interventions should focus only on modifiable behaviors where there is evidence that such modification will improve health. Weight is not a behavior and therefore not an appropriate target for behavior modification.

- Lay experience should inform practice, and the political dimensions of health research and policy should be articulated.

These guidelines outline ways in which health practitioners can shift their practice towards a HAES approach and, in so doing, uphold the tenets of their profession in providing inclusive, effective, and ethical care consistent with the evidence base.

\section{Appendix}

${ }^{1}$ Critics challenge the value of using BMI terminology, suggesting that BMI is a poor determinant of health and the categories medicalize and pathologize having a certain body. We accept this argument; we have used "overweight" and "obese" throughout this paper when necessary to report research where these categories were used. We recognize, however, that "normal" does not reflect a normative or optimal value; that "overweight" falsely implies a weight over which one is unhealthy; and that the etymology of the word "obese" mistakenly implies that a large appetite is the cause.

${ }^{2}$ Health at Every Size/HAES is a pending trademark of the Association for Size Diversity and Health.

\section{Acknowledgements}

Deb Burgard conceptualized the obesity cost analysis. The authors thank Deb Burgard, Sigrún Daníelsdóttir, Paul Ernsberger, Janell Mensinger, Elise Paradis, Jon Robison, Camerin Ross, Abigail Saguy, and Evelyn Tribole for their contributions and critical review. Lucy Aphramor thanks the WM NMAHP Research Training Awards for financial support.

\section{Author details}

${ }^{1}$ University of California, Davis, and City College of San Francisco, Box S-80, City College of San Francisco, 50 Phelan Avenue, San Francisco,

CA 94112, USA. ${ }^{2}$ Coventry University, Applied Research Centre in Health and Lifestyle Interventions, Priory Street, Coventry, CV1 1FB, UK. ${ }^{3}$ University Hospitals Coventry and Warwickshire NHS Trust, Cardiac Rehab, Cardiology Suite, 1st Floor, East Wing, Walsgrave Hospital, Clifford Bridge Road, Coventry CV2 2DX, UK.

\section{Authors' contributions}

LB initiated the collaboration. Both authors contributed to conceptualizing and drafting the review. LB was lead researcher and undertook the systematic review and designed and completed the tables. Both authors approved the final manuscript.

\section{Conflicts of interests Disclosure}

Linda Bacon and Lucy Aphramor are HAES practitioners. Both also speak and write on the topic of Health at Every Size and sometimes receive financial remuneration for this work.

Received: 1 October 2010 Accepted: 24 January 2011

Published: 24 January 2011

\section{References}

1. Marketdata Enterprises: The U.S. Weight Loss \& Diet Control Market (10th Edition). Lynbrook 2009.

2. Monteath SA, McCabe MP: The influence of societal factors on female body image. J Soc Psychol 1997, 137:708-727.

3. Neumark-Sztainer D, Rock CL, Thornquist MD, Cheskin LJ, Neuhouser ML, Barnett MJ: Weight-control behaviors among adults and adolescents: Associations with dietary intake. Prev Med 2000, 30:381-391.

4. Jeffery RW, Adlis SA, Forster JL: Prevalence of dieting among working men and women: The Healthy Worker Project. Health Psychol 1991, 10:274-281.

5. Mann T, Tomiyama AJ, Westling E, Lew AM, Samuels B, Chatman J: Medicare's Search for Effective Obesity Treatments: Diets Are Not the Answer. Am Psychol 2007, 62:220-233 
6. Neumark-Sztainer D: Preventing obesity and eating disorders in adolescents: what can health care providers do? J Adolesc Health 2009, 44:206-213.

7. Daníelsdóttir S, Burgard D, Oliver-Pyatt W: AED Guidelines for Childhood Obesity Prevention Programs. Academy of Eating Disorders; 2009.

8. Bacon L: Health at Every Size: The Surprising Truth About Your Weight. Second edition. Dallas: BenBella Books; 2010.

9. Schmidt H, Voigt K, Wikler D: Carrots, Sticks, and Health Care Reform Problems with Wellness Incentives. N Engl J Med 2009, 362:e3.

10. Medical News Today: Eating Disorder Organizations Join Forces To Urge Focus On Health And Lifestyle Rather Than Weight. 2009

11. Bacon L, Stern J, Van Loan M, Keim N: Size acceptance and intuitive eating improve health for obese, female chronic dieters. J Am Diet Assoc 2005, 105:929-936.

12. Ciliska D: Evaluation of two nondieting interventions for obese women. West J Nurs Res 1998, 20:119-135.

13. Goodrick GK, Poston WSC II, Kimball KT, Reeves RS, Foreyt JP: Nondieting versus dieting treatment for overweight binge-eating women. $J$ Consult Clin Psychol 1998, 66:363-368

14. Tanco S, Linden W, Earle T: Well-being and morbid obesity in women: A controlled therapy evaluation. Int J Eat Disord 1998, 23:325-339.

15. Miller WC, Wallace JP, Eggert KE, Lindeman AK: Cardiovascular risk reduction in a self-taught, self-administered weight loss program called the nondiet diet. Med Exerc Nutr Health 1993, 2:218-223.

16. Rapoport L, Clark M, Wardle J: Evaluation of a modified cognitive-behavioural programme for weight management. Int J Obes 2000, 24:1726-1737.

17. Provencher V, Begin C, Tremblay A, Mongeau L, Corneau L, Dodin S, Boivin S, Lemieux S: Health-at-every-size and eating behaviors: 1-year follow-up results of a size acceptance intervention. J Am Diet Assoc 2009, 109:1854-1861.

18. Mensinger J, Close $\mathrm{H}, \mathrm{Ku}$ J: Intuitive eating: A novel health promotion strategy for obese women. Paper presented at American Public Health Association. Philadelphia, PA 2009.

19. Bacon L, Keim N, Van Loan M, Derricote M, Gale B, Kazaks A, Stern J: Evaluating a "Non-diet" Wellness Intervention for Improvement of Metabolic Fitness, Psychological Well-Being and Eating and Activity Behaviors. Int J Obes 2002, 26:854-865.

20. Provencher V, Bégin C, Tremblay A, Mongeau L, Boivin S, Lemieux S: Shortterm effects of a "health-at-every-size" approach on eating behaviors and appetite ratings. Obesity (Silver Spring) 2007, 15:957-966.

21. Steinhardt M, Bezner J, Adams T: Outcomes of a traditional weight control program and a nondiet alternative: a one-year comparison. J Psychol 1999, 133:495-513.

22. Carrier KM, Steinhardt MA, Bowman S: Rethinking traditional weight management programs: A 3-year follow-up evaluation of a new approach. J Psychol 1993, 128:517-535.

23. Omichinski $L$, Harrison KR: Reduction of dieting attitudes and practices after participation in a non-diet lifestyle program. J Can Diet Assoc 1995, 56:81-85.

24. Polivy J, Herman CP: Undieting: A program to help people stop dieting. Int J Eat Disord 1992, 11:261-268.

25. Roughan P, Seddon E, Vernon-Roberts J: Long-term effects of a psychologically based group programme for women preoccupied with body weight and eating behaviour. Int J Obes 1990, 14:135-147.

26. Higgins L, Gray W: Changing the body image concern and eating behaviour of chronic dieters: the effects of a psychoeducational intervention. Psychol and Health 1998, 13:1045-1060.

27. Miller WC: How effective are traditional dietary and exercise interventions for weight loss? Med Sci Sports Exerc 1999, 31:1129-1134.

28. National Institutes of Health (NIH): Methods for voluntary weight loss and control (Technology Assessment Conference Panel). Ann Intern Med 1992, 116:942-949.

29. Gregg EW, Gerzoff RB, Thompson TJ, Williamson DF: Intentional weight loss and death in overweight and obese U.S. adults 35 years of age and older. Ann Intern Med 2003, 138:383-389.

30. Wamala S, Lynch J, Horsten M: Education and the Metabolic Syndrome in Women. Diabetes Care 1999, 22:1999-2003.

31. Aphramor L: Validity of claims made in weight management research: a narrative review of dietetic articles. Nutr J 2010, 9:30.

32. Flegal KM, Graubard BI, Williamson DF, Gail MH: Excess deaths associated with underweight, overweight, and obesity. JAMA 2005, 293:1861-1867.
33. Durazo-Arvizu R, McGee D, Cooper R, Liao Y, Luke A: Mortality and optimal body mass index in a sample of the US population. Am J Epidemiol 1998, 147:739-749.

34. Troiano R, Frongillo E Jr, Sobal J, Levitsky D: The relationship between body weight and mortality: A quantitative analysis of combined information from existing studies. Int J Obes Relat Metab Disord 1996, 20:63-75.

35. Flegal K, Graubard B, Williamson D, Gail M: Supplement: Response to "Can Fat Be Fit". Sci Am 2008, 297:5-6.

36. McGee DL: Body mass index and mortality: a meta-analysis based on person-level data from twenty-six observational studies. Ann Epidemiol 2005, 15:87-97.

37. Janssen I, Mark AE: Elevated body mass index and mortality risk in the elderly. Obes Rev 2007, 8:41-59.

38. Lantz PM, Golberstein E, House JS, Morenoff J: Socioeconomic and behavioral risk factors for mortality in a national 19-year prospective study of U.S. adults. Soc Sci Med 2010, 70:1558-1566.

39. Berrington de Gonzalez A, Hartge P, Cerhan JR, Flint AJ, Hannan L, MacInnis RJ, Moore SC, Tobias GS, Anton-Culver H, Freeman LB, et al: Bodymass index and mortality among 1.46 million white adults. $N$ Engl J Med 2010, 363:2211-2219.

40. Childers D, Allison D: The 'obesity paradox': a parsimonious explanation for relations among obesity, mortality rate and aging? Int J Obes (Lond) 2010, 34:1231-1238.

41. Morse S, Gulati R, Reisin E: The obesity paradox and cardiovascular disease. Curr Hypertens Rep 2010, 12:120-126.

42. Ross C, Langer RD, Barrett-Connor E: Given diabetes, is fat better than thin? Diabetes Care 1997, 20:650-652.

43. Barrett-Connor $E$, Khaw K: Is hypertension more benign when associated with obesity? Circulation 1985, 72:53-60

44. Barrett-Connor EL: Obesity, atherosclerosis and coronary artery disease. Ann Intern Med 1985, 103:1010-1019.

45. Kang X, Shaw LJ, Hayes SW, Hachamovitch R, Abidov A, Cohen I, Friedman JD, Thomson LE, Polk D, Germano G, Berman DS: Impact of body mass index on cardiac mortality in patients with known or suspected coronary artery disease undergoing myocardial perfusion single-photon emission computed tomography. J Am Coll Cardiol 2006, 47:1418-1426.

46. Beddhu S: The body mass index paradox and an obesity, inflammation, and atherosclerosis syndrome in chronic kidney disease. Seminars in Dialysis 2004, 17:229-232

47. Ernsberger P, Haskew P: Health implications of obesity: An alternative view. J of Obesity and Weight Regulation 1987, 9:39-40.

48. Ernsberger $P$, Koletsky RJ: Biomedical rationale for a wellness approach to obesity: An alternative to a focus on weight loss. J Soc Issues 1999, 55:221-260.

49. Lavie CJ, Milani RV, Ventura HO: Obesity, heart disease, and favorable prognosis-truth or paradox? Am J Med 2007, 120:825-826.

50. Gruberg L, Mercado N, Milo S, Boersma E, Disco C, van Es GA, Lemos PA, Ben Tzvi M, Wijns W, Unger F, et al: Impact of body mass index on the outcome of patients with multivessel disease randomized to either coronary artery bypass grafting or stenting in the ARTS trial: The obesity paradox II? Am J Cardiol 2005, 95:439-444.

51. Lavie CJ, Osman AF, Milani RV, Mehra MR: Body composition and prognosis in chronic systolic heart failure: the obesity paradox. Am J Cardiol 2003, 91:891-894.

52. Schmidt DS, Salahudeen AK: Obesity-survival paradox-still a controversy? Semin Dial 2007, 20:486-492

53. Kulminski AM, Arbeev KG, Kulminskaya IV, Ukraintseva SV, Land K, Akushevich I, Yashin Al: Body mass index and nine-year mortality in disabled and nondisabled older U.S. individuals. J Am Geriatr Soc 2008, 56:105-110.

54. Olshansky SJ, Passaro DJ, Hershow RC, Layden J, Carnes BA, Brody J, Hayflick L, Butler RN, Allison DB, Ludwig DS: A potential decline in life expectancy in the United States in the 21st century. N Engl J Med 2005, 352:1138-1145

55. Belluck P: Children's Life Expectancy Being Cut Short by Obesity. New York Times. New York City; 2005.

56. Carmona R: Testimony Before the Subcommittee on Competition, Infrastructure, and Foreign Commerce Committee on Commerce, Science, and Transportation. United States Senate 2004. 
57. White House Task Force on Childhood Obesity: Solving the Problem of Childhood Obesity Within a Generation. Report to the White House. 2010.

58. National Center for Health Statistics: Health, United States, 2007. With Chartbook on Trends in the Health of Americans. Hyattsville, MD 2007.

59. Mathers C, Loncar D: Projections of Global Mortality and Burden of Disease from 2002 to 2030. PLoS Med 2006, 3:2011-2029.

60. Social Security Administration: Periodic Life Table. 2007, (updated 7/9/07).

61. Campos P, Saguy A, Ernsberger P, Oliver E, Gaesser G: The epidemiology of overweight and obesity: public health crisis or moral panic? Int J Epidemiol 2005, 35:55-60

62. Kruger J, Galuska DA, Serdula MK, Jones DA: Attempting to lose weight: specific practices among U.S. adults. Am J Prev Med 2004, 26:402-406.

63. Strohacker K, McFarlin B: Influence of obesity, physical inactivity, and weight cycling on chronic inflammation. Front Biosci 2010, E2:98-104.

64. Montani JP, Viecelli AK, Prevot A, Dulloo AG: Weight cycling during growth and beyond as a risk factor for later cardiovascular diseases: the 'repeated overshoot' theory. Int J Obes (Lond) 2006, 30(Suppl 4):S58-66.

65. Olson MB, Kelsey SF, Bittner V, Reis SE, Reichek N, Handberg EM, Merz CN: Weight cycling and high-density lipoprotein cholesterol in women: evidence of an adverse effect: a report from the NHLBI-sponsored WISE study. Women's Ischemia Syndrome Evaluation Study Group. J Am Coll Cardiol 2000, 36:1565-1571.

66. French SA, Jeffrey RW, Forster JL, McGovern PG, Kelder SH, Baxter J: Predictors of weight change over two years among a population of working adults: The Healthy Worker Project. Int J Obes 1994, 18:145-154.

67. Guagnano MT, Pace-Palitti V, Carrabs C, Merlitti D, Sensi S: Weight fluctuations could increase blood pressure in android obese women. Clinical Sciences (London) 1999, 96:677-680.

68. Rzehak P, Meisinger C, Woelke G, Brasche S, Strube G, Heinrich J: Weight change, weight cycling and mortality in the ERFORT Male Cohort Study. Eur J Epidemiol 2007, 22:665-673.

69. Lissner L, Odell PM, D'Agostino RB, Stokes J, Kreger BE, Belanger AJ, Brownell KD: Variability of body weight and health outcomes in the Framingham population. N Engl J Med 1991, 324:1839-1844.

70. Diaz VA, Mainous AG, Everett CJ: The association between weight fluctuation and mortality: results from a population-based cohort study. J Community Health 2005, 30:153-165.

71. McDermott R: Ethics, Epidemiology, and the Thrifty Gene: Biological Determinism as a Health Hazard. Soc Sci Med 1998, 47:1189-1195.

72. Brunner E, Marmot M: Social Organization, Stress, and Health. In Social Determinants of Health. 2 edition. Edited by: Marmot M, Wilkinson RG. New York: Oxford University Press; 2006:17-43.

73. Raphael D, Lines E, Bryant T, Daiski I, Pilkington B, Dinca-Panaitescu S, Dinca-Panaitescu M: Type 2 Diabetes: Poverty, Priorities and Policy. The Social Determinants of the Incidence and Management of Type 2 Diabetes Toronto: York University School of Health Policy and Management and School of Nursing; 2010

74. Charles MA, Pettitt DJ, Saad MF, Nelson RG, Bennett PH, Knowler WC: Development of impaired glucose tolerance with or without weight gain. Diabetes Care 1993, 16:593-596.

75. Odeleye OE, de Courten M, Pettitt DJ, Ravussin E: Fasting hyperinsulinemia is a predictor of increased body weight gain and obesity in Pima Indian children. Diabetes 1997, 46:1341-1345

76. Sigal RJ, El-Hashimy M, Martin BC, Soeldner JS, Krolewski AS, Warram JH: Acute postchallenge hyperinsulinemia predicts weight gain: a prospective study. Diabetes 1997, 46:1025-1029.

77. Yost TJ, Jensen DR, Eckel RH: Weight regain following sustained weight reduction is predicted by relative insulin sensitivity. Obes Res 1995, 3:583-587

78. Halberg N, Henriksen M, Söderhamn N, Stallknecht B, Ploug T, Schjerling P, Dela F: Effect of intermittent fasting and refeeding on insulin action in healthy men. J Appl Physiol 2005, 99:2128-2136.

79. Akram DS, Astrup AV, Atinmo T, Boisson JL, Bray GA, Carroll KK, Chunming C, Chitson P, Dietz WH, Hill JO, et al: Obesity: Preventing and managing the global epidemic. Report of a WHO consultation on obesity Geneva, Switzerland: World Health Organization; 1997.

80. Weinsier RL, Norris DJ, Birch R, Bernstein RS, Wang J, Yang MU, Pierson RN $\mathrm{Jr}$, Van Itallie TB: The relative contribution of body fat and fat pattern to blood pressure level. Hypertension 1985, 7:578-585.
81. Ernsberger $P$, Nelson DO: Effects of fasting and refeeding on blood pressure are determined by nutritional state, not by body weight change. Am J Hypertens 1988, 153S-157S.

82. Schulz M, Liese A, Boeing H, Cunningham J, Moore C, Kroke A: Associations of short-term weight changes and weight cycling with incidence of essential hypertension in the EPIC-Potsdam Study. J Hum Hypertens 2005, 19:61-67.

83. Ernsberger P, Koletsky RJ, Baskin JZ, Collins LA: Consequences of weight cycling in obese spontaneously hypertensive rats. Am J Physiol 1996, 270: R864-R872.

84. Ernsberger P, Koletsky RJ, Baskin JZ, Foley M: Refeeding hypertension in obese spontaneously hypertensive rats. Hypertension 1994, 24:699-705.

85. Chernin K: The Obsession: Reflections on the tyranny of slenderness New York: Harper \& Row; 1981

86. Cambien F, Chretien J, Ducimetiere L, Guize L, Richard J: Is the relationship between blood pressure and cardiovascular risk dependent on body mass index? Am J Epidemiol 1985, 122:434-442.

87. Weinsier R, James L, Darnell B, Dustan H, Birch R, Hunter G: Body fat: Its relationship to coronary heart disease, blood pressure, lipids, and other risk factors measured in a large male population. Am J Med 1976, 61:815-824.

88. Uretsky S, Messerli FH, Bangalore S, Champion A, Cooper-Dehoff RM, Zhou Q, Pepine CJ: Obesity paradox in patients with hypertension and coronary artery disease. Am J Med 2007, 120:863-870.

89. Messerli FH: Cardiovascular adaptations to obesity and arterial hypertension: detrimental or beneficial? Int J Cardiol 1983, 3:94-97.

90. Gregg EW, Cheng YJ, Cadwell BL, Imperatore G, Williams DE, Flegal KM, Narayan KM, Williamson DF: Secular trends in cardiovascular disease risk factors according to body mass index in US adults. JAMA 2005, 293:1868-1874.

91. Williamson DF, Pamuk E, Thun M, Flanders D, Byers T, Heath C: Prospective study of intentional weight loss and mortality in never-smoking overweight U.S. white women aged 40-64 years. Am J Epidemiol 1995 141:1128-1141.

92. Williamson DF, Pamuk E, Thun M, Flanders D, Byers T, Heath C: Prospective study of intentional weight loss and mortality in overweight white men aged 40-64 years. Am J Epidemiol 1999, 149:491-503.

93. Andres R, Muller DC, Sorkin JD: Long-term effects of change in body weight on all-cause mortality. A review. Ann Intern Med 1993, 119:737-743.

94. Yaari S, Goldbourt U: Voluntary and involuntary weight loss: associations with long term mortality in 9,228 middle-aged and elderly men. Am J Epidemiol 1998, 148:546-555.

95. Sørensen T, Rissanen A, Korkeila M, Kaprio J: Intention to lose weight, weight changes, and 18-y mortality in overweight individuals without co- morbidities. PLOS Med 2005, 2:E171.

96. Simonsen MK, Hundrup YA, Obel EB, Gronbaek M, Heitmann BL: Intentional weight loss and mortality among initially healthy men and women. Nutr Rev 2008, 66:375-386.

97. Ingram DD, Mussolino ME: Weight loss from maximum body weight and mortality: the Third National Health and Nutrition Examination Survey Linked Mortality File. Int J Obes 2010, 34:1044-1050.

98. Klein S, Fontana L, Young VL, Coggan AR, Kilo C, Patterson BW, Mohammed BS: Absence of an effect of liposuction on insulin action and risk factors for coronary heart disease. N Engl J Med 2004, 350:2549-2557.

99. Manning RM, Jung RT, Leese GP, Newton RW: The comparison of four weight reduction strategies aimed at overweight patients with diabetes mellitus: four-year follow-up. Diabet Med 1998, 15:497-502.

100. Wing RR, Anglin K: Effectiveness of a behavioral weight control program for blacks and whites with NIDDM. Diabetes Care 1996, 19:409-413.

101. Ciliska D, Kelly C, Petrov N, Chalmers J: A review of weight loss interventions for obese people with non-insulin dependent diabetes mellitus. Can J of Diabetes Care 1995, 19:10-15.

102. Howard BV, Manson JE, Stefanick ML, Beresford SA, Frank G, Jones B, Rodabough RJ, Snetselaar L, Thomson C, Tinker L, et al: Low-fat dietary pattern and weight change over 7 years: the Women's Health Initiative Dietary Modification Trial. JAMA 2006, 295:39-49.

103. Howard BV, Van Horn L, Hsia J, Manson JE, Stefanick ML, WassertheilSmoller S, Kuller LH, LaCroix AZ, Langer RD, Lasser NL, et al: Low-fat dietary pattern and risk of cardiovascular disease: the Women's Health Initiative 
Randomized Controlled Dietary Modification Trial. JAMA 2006, 295:655-666.

104. Aphramor L: Is A Weight-Centred Health Framework Salutogenic? Some Thoughts on Unhinging Certain Dietary Ideologies. Social Theory and Health 2005, 3:315-340

105. Aphramor $L$ : Weight management as a cardioprotective intervention raises issues for nutritional scientists regarding clinical ethics. Proc Nut Soc 2009, 67:E401.

106. Sjostrom L, Lindroos AK, Peltonen M, Torgerson J, Bouchard C, Carlsson B, Dahlgren S, Larsson B, Narbro K, Sjostrom CD, et al: Lifestyle, diabetes, and cardiovascular risk factors 10 years after bariatric surgery. N Engl I Med 2004, 351:2683-2693

107. Christou NV, Look D, Maclean LD: Weight gain after short- and long-limb gastric bypass in patients followed for longer than 10 years. Ann Surg 2006, 244:734-740.

108. Bacon L, Stern JS, Keim NL, Van Loan MD: Low bone mass in premenopausal chronic dieting obese women. Eur J Clin Nutr 2004, 58:966-971.

109. Van Loan MD, Keim NL: Influence of cognitive eating restraint on totalbody measurements of bone mineral density and bone mineral content in premenopausal women $18-45 \mathrm{y}$ : a cross-sectional study. Am J Clin Nutr 2000, 72:837-843.

110. Van Loan MD, Bachrach LK, Wang MC, Crawford PB: Effect of drive for thinness during adolescence on adult bone mass. J Bone Miner Res 2000, 15:S412.

111. Barr SI, Prior JC, Vigna YM: Restrained eating and ovulatory disturbances: Possible implications for bone health. Am J Clin Nutr 1994, 59:92-97.

112. Tomiyama AJ, Mann T, Vinas D, Hunger JM, Dejager J, Taylor SE: Low calorie dieting increases cortisol. Psychosom Med 2010, 72:357-364.

113. Lee DH, Lee IK, Song K, Steffes M, Toscano W, Baker BA, Jacobs DR Jr: A strong dose-response relation between serum concentrations of persistent organic pollutants and diabetes: results from the National Health and Examination Survey 1999-2002. Diabetes Care 2006, 29:1638-1644.

114. Carpenter DO: Environmental contaminants as risk factors for developing diabetes. Rev Environ Health 2008, 23:59-74.

115. Ha MH, Lee DH, Jacobs DR: Association between serum concentrations of persistent organic pollutants and self-reported cardiovascular disease prevalence: results from the National Health and Nutrition Examination Survey, 1999-2002. Environ Health Perspect 2007, 115:1204-1209.

116. Lee DH, Steffes M, Jacobs DR: Positive associations of serum concentration of polychlorinated biphenyls or organochlorine pesticides with self-reported arthritis, especially rheumatoid type, in women. Environ Health Perspect 2007, 115:883-888.

117. Chevrier J, Dewailly E, Ayotte P, Mauriege P, Despres JP, Tremblay A: Body weight loss increases plasma and adipose tissue concentrations of potentially toxic pollutants in obese individuals. Int J Obes Relat Metab Disord 2000, 24:1272-1278.

118. Lim JS, Son HK, Park SK, Jacobs DR Jr, Lee DH: Inverse associations between long-term weight change and serum concentrations of persistent organic pollutants. Int J Obes (Lond) 2010.

119. Davison KK, Markey CN, Birch LL: A longitudinal examination of patterns in girls' weight concerns and body dissatisfaction from ages 5 to 9 years. Int J Eat Disord 2003, 33:320-332.

120. Holm S: Obesity interventions and ethics. Obes Rev 2007, 8(Suppl 1):207-210.

121. Neumark-Sztainer D, Levine MP, Paxton SJ, Smolak L, Piran N, Wertheim EH: Prevention of body dissatisfaction and disordered eating: What next? Eat Disord 2006, 14:265-285.

122. van den Berg $P$, Neumark-Sztainer D: Fat ' $n$ happy 5 years later: is it bad for overweight girls to like their bodies? I Adolesc Health 2007, 41:415-417.

123. Stice E, Cameron RP, Killen JD, Hayward C, Taylor CB: Naturalistic weightreduction efforts prospectively predict growth in relative weight and onset of obesity among female adolescents. J Consult Clin Psychol 1999, 67:967-974.

124. Coakley EH, Rimm EB, Colditz G, Kawachi I, Willett W: Predictors of weight change in men: Results from the Health Professionals Follow-Up Study. Int J Obes Relat Metab Disord 1998, 22:89-96.

125. Bild DE, Sholinksy P, Smith DE, Lewis CE, Hardin JM, Burke GL: Correlates and predictors of weight loss in young adults: The CARDIA study. Int J Obes Relat Metab Disord 1996, 20:47-55.
126. Korkeila M, Rissanen A, Kapriio J, Sorensen TIA, Koskenvuo M: Weight-loss attempts and risk of major weight gain. Am J Clin Nutr 1999, 70:965-973

127. Neumark-Sztainer D, Wall M, Guo J, Story M, Haines J, Eisenberg M: Obesity, disordered eating, and eating disorders in a longitudinal study of adolescents: how do dieters fare 5 years later? J Am Diet Assoc 2006, 106:559-568.

128. Field AE, Austin SB, Taylor CB, Malspeis S, Rosner B, Rockett HR, Gillman MW, Colditz GA: Relation between dieting and weight change among preadolescents and adolescents. Pediatrics 2003, 112:900-906.

129. Puhl RM, Andreyeva T, Brownell KD: Perceptions of weight discrimination: prevalence and comparison to race and gender discrimination in America. Int J Obes (Lond) 2008, 32:992-1000.

130. Brownell K, Puhl R, Schwartz M, Rudd LE: Weight bias: Nature, consequences, and remedies New York: Guilford; 2005.

131. Puhl RM, Brownell KD: Confronting and coping with weight stigma: an investigation of overweight and obese adults. Obesity (Silver Spring) 2006, 14:1802-1815.

132. Haines J, Neumark-Sztainer D, Eisenberg ME, Hannan PJ: Weight teasing and disordered eating behaviors in adolescents: longitudinal findings from Project EAT (Eating Among Teens). Pediatrics 2006, 117:e209-215.

133. Neumark-Sztainer D, Falkner N, Story M, Perry C, Hannan PJ, Mulert S: Weight-teasing among adolescents: correlations with weight status and disordered eating behaviors. Int I Obes Relat Metab Disord 2002, 26:123-131.

134. Puhl RM, Moss-Racusin CA, Schwartz MB: Internalization of weight bias: Implications for binge eating and emotional well-being. Obesity (Silver Spring) 2007, 15:19-23.

135. Faith MS, Leone MA, Ayers TS, Heo M, Pietrobelli A: Weight criticism during physical activity, coping skills, and reported physical activity in children. Pediatrics 2002, 110:e23.

136. Storch EA, Milsom VA, Debraganza N, Lewin AB, Geffken GR, Silverstein JH: Peer victimization, psychosocial adjustment, and physical activity in overweight and at-risk-for-overweight youth. J Pediatr Psychol 2007, 32:80-89.

137. Vartanian LR, Shaprow JG: Effects of weight stigma on exercise motivation and behavior: a preliminary investigation among collegeaged females. J Health Psychol 2008, 13:131-138.

138. Amy N, Aalborg A, Lyons P, Keranen L: Barriers to routine gynecological cancer screening for White and African-American obese women. Int $J$ Obes Relat Metab Disord 2006, 30:147-155.

139. Puhl R, Brownell K: Bias, discrimination and obesity. Obes Res 2001, 9:788-805.

140. Puhl RM, Heuer CA: The stigma of obesity: a review and update. Obesity (Silver Spring) 2009, 17:941-964.

141. Fagard RH: Physical activity in the prevention and treatment of hypertension in the obese. Med Sci Sports Exerc 1999, 31:S624-630.

142. Appel L, Moore TJ, Obarzanek E, Vollmer WM, Svetkey LP, Sacks FM, Bray GA, Vogt TM, Cutler JA, Windhauser MM, et al: A clinical trial of the effects of dietary patterns on blood pressure. N Engl J Med 1997, 33:1117-1124.

143. Gaesser GA: Exercise for prevention and treatment of cardiovascular disease, type 2 diabetes, and metabolic syndrome. Curr Diab Rep 2007, 7:14-19.

144. Kraus WE, Houmard JA, Duscha BD, Knetzger KJ, Wharton MB, McCartney JS, Bales CW, Henes S, Samsa GP, Otvos JD, et al: Effects of the amount and intensity of exercise on plasma lipoproteins. N Engl J Med 2002, 347:1483-1492.

145. Lamarche B, Despres JP, Pouliot MC, Moorjani S, Lupien PJ, Theriault G, Tremblay A, Nadeau A, Bouchard C: Is body fat loss a determinant factor in the improvement of carbohydrate and lipid metabolism following aerobic exercise training in obese women? Metabolism 1992, 41:1249-1256

146. Bjorntorp P, DeJounge K, Sjostrom L, Sullivan L: The effect of physical training on insulin production in obesity. Metabolism 1970, 19:631-638

147. Finkelstein EA, Trogdon JG, Cohen JW, Dietz W: Annual medical spending attributable to obesity: payer-and service-specific estimates. Health Aff (Millwood) 2009, 28:w822-831

148. Wildman RP, Muntner P, Reynolds K, McGinn AP, Rajpathak S, WylieRosett J, Sowers MR: The obese without cardiometabolic risk factor clustering and the normal weight with cardiometabolic risk factor clustering: prevalence and correlates of 2 phenotypes among the US population (NHANES 1999-2004). Arch Intern Med 2008, 168:1617-1624. 
149. Beaglehole R, Prior IA, Foulkes MA, Eyles EF: Death in the South Pacific. N Z Med J 1980, 91:375-378.

150. Crister G: Fat Land: How Americans Became the Fattest People in the World New York: Houghton Mifflin; 2004.

151. Heinberg L, Matzon J: Body image dissatisfaction as a motivator for healthy lifestyle change: Is some distress beneficial? In Eating disorders: Innovative directions for research and practice. Edited by: Striegel-Moore R, Smolak L. Washington, DC: American Psychological Association; 2001:215-232

152. Puhl R, Heuer C: Obesity Stigma: Important Considerations for Public Health. Am J Public Health 2010, 100:1019-1028.

153. Leary MR, Tate EB, Adams CE, Allen AB, Hancock J: Self-compassion and reactions to unpleasant self-relevant events: the implications of treating oneself kindly. J Pers Soc Psychol 2007, 92:887-904.

154. Goss K, Allen S: Compassion focused therapy for eating disorders. Int J of Cognitive Therapy 2010, 3:141-158.

155. Aphramor L, Gingras J: That remains to be seen: Disappeared feminist discourses on fat in dietetic theory and practice. In The Fat Studies Reader. Edited by: Rothblum E, Solovay S. New York: New York University Press; 2009:97-105

156. Tribole E, Resch E: Intuitive eating: a revolutionary program that works. 2 edition. New York: St. Martin's Griffin; 2010.

157. Hirschmann JR, Munter CH: When women stop hating their bodies: freeing yourself from food and weight obsession. 1 edition. New York: Fawcett Columbine; 1995.

158. Matz J, Frankel E: The Diet Survivor's Handbook: 60 Lessons in Eating, Acceptance and Self-care Naperville, IL: Sourcebooks; 2006

159. May M: Eat What You Love, Love What You Eat: How to Break Your EatRepent-Repeat Cycle Greenleaf Book Group Press; 2009.

160. Satter E: Secrets of Feeding a Healthy Family: How to Eat, How to Raise Good Eaters and How to Cook Madison, Wl: Kelcy Press; 2008.

161. Cole R, Horacek T: Effectiveness of the "My Body Knows When" intuitiveeating pilot program. Am J Health Behav 2010, 34:286-297.

162. Smith T, Hawks S: Intuitive eating, diet composition and the meaning of food in healthy weight promotion. Am J Health Educ 2006, 37:130-136.

163. Tylka T: Development and psychometric evaluation of a measure of intuitive eating. I Couns Psychol 2006, 53:226-240.

164. Kristeller J, Hallett C: An exploratory study of a meditation-based intervention for binge eating disorder. J Health Psychol 1999, 4:357-363.

165. Smitham $L$ : Evaluating an intuitive eating program for binge eating disorder: A benchmarking study [dissertation]. South Bend, IN: University of Notre Dame; 2008.

166. Hawks S, Madanat H, Hawks J, Harris A: The relationship between intuitive eating and health indicators among college women. Am J Health Educ 2005, 36:331-336.

167. Weigensberg M, Shoar Z, Lane C, Spruiitt-Metz D: Intuitive eating (IE) Is associated with decreased adiposity and increased insulin sensitivity (Si) in obese Latina female adolescents. DiabetesPro; 2009.

168. Aphramor L, Gingras J: Helping People Change: Promoting Politicised Practice in the Healthcare Professions. In Debating Obesity: Critical Perspectives. Edited by: Rich E, Monaghan L, Aphramor L. U.K.: Palgrave/ Macmillan; 2010.

169. Aphramor L, Gingras J: Weight in Practice, Health in Perspective. In Critical Bodies. Edited by: Riley S, Burns M, Frith H, Wiggins S, Markula P. Palgrave/ Macmillan; 2007:155-117.

170. Bacon L: Reflections on Fat Acceptance: Lessons Learned from Privilege. Keynote Speech, National Association to Advance Fat Acceptance conference; Washington, DC 2009 [http://www.lindabacon.org/ Bacon_ThinPrivilege080109.pdf].

171. Marmot MG: Status syndrome: a challenge to medicine. JAMA 2006, 295:1304-1307.

172. Clarke P, O'Malley PM, Johnston LD, Schulenberg JE: Social disparities in BMI trajectories across adulthood by gender, race/ethnicity and lifetime socio-economic position: 1986-2004. Int J Epidemiol 2009, 38:499-509.

173. Chandola T, Brunner E, Marmot M: Chronic stress at work and the metabolic syndrome: prospective study. BMJ 2006, 332:521-525.

174. Vitaliano PP, Scanlan JM, Zhang J, Savage MV, Hirsch IB, Siegler IC: A path model of chronic stress, the metabolic syndrome, and coronary heart disease. Psychosom Med 2002, 64:418-435.
175. Raikkonen K, Matthews KA, Kuller LH: The relationship between psychological risk attributes and the metabolic syndrome in healthy women: antecedent or consequence? Metabolism 2002, 51:1573-1577.

176. Aphramor L: Disability and the Anti-Obesity Offensive. Disability \& Society 2009, 24:897-909.

177. Lebesco K: Fat Panic and the New Morality. In Against Health: How Health Became the New Morality. Edited by: Metzl J, Kirkland A. New York: New York University Press; 2010:72-82.

178. Klein R: What is Health and How Do You Get It? In Against Health: How Health Became the New Morality. Edited by: Metzl J, Kirkland A. New York: New York University Press; 2010:15-25.

doi:10.1186/1475-2891-10-9

Cite this article as: Bacon and Aphramor: Weight Science: Evaluating the

Evidence for a Paradigm Shift. Nutrition Journal 2011 10:9.

\section{Submit your next manuscript to BioMed Central and take full advantage of:}

- Convenient online submission

- Thorough peer review

- No space constraints or color figure charges

- Immediate publication on acceptance

- Inclusion in PubMed, CAS, Scopus and Google Scholar

- Research which is freely available for redistribution

Submit your manuscript at www.biomedcentral.com/submit
C Biomed Central 